\title{
Key to the Species of the Genus Typhlodromips (Acari: Phytoseiidae) with A New and A Newly Recorded Species in Korea
}

\author{
Myon Ok Ryu*
}

Yangdong Middle School, Yangcheon-gu, Seoul 158-511, Korea

\section{한국산 비단이리응애속의 종 검색표 및 1 신종과 1 한국미기록종의 기재 \\ 류면옥* \\ 서울 양동중학교}

\begin{abstract}
Typhlodromips geumgangensis $\mathrm{n}$. sp. is described in Korea. Typhlodromips paraki, newly recorded species from this country, is redescribed based on Korean specimens, and key to the species of the genus Typhlodromips is provided.
\end{abstract}

Key words: Phytoseiidae, Typhlodromips, New species, Newly recorded species, Korea, key, Typhlodromips geumgangensis, Typhlodromips paraki

초 록: 이리응애 1 신종인 Typhlodromips geumgangensis n. sp. (금강이리응애)를 기재하였고, 1 한국 미기록종인 Typhlodromips paraki (Ehara, 1967) (명아주이리응애)를 한국산 표본으로 재 기재하였으며, 비단이리응애속의 종 검색표를 제시하였다.

검색어: 이리응애과, 비단이리응애속, 신종, 미기록종, 한국, 검색표, 금강이리응애, 명아주이리응애

Many species of the phytoseiid mites are predaceous mites that occur on a wide range of plants in association with phytophagous mites and insect. The genus Typhlodromips is characterized by 17 pairs (j1, j3, j4, j5, j6, J2, J5, z2, z4, z5, Z1, Z4, Z5, s4, S2, S4, and S5) of setae on the dorsal shield of an adult female. Typhlodromips has macrosetae on the genu of legs I, II, III, and IV, furthermore, leg IV bears macrosetae on tibia and basitarsus. Seta Z5 shorter than, or approximately as long as distance between bases of Z5. Up to the present, ten species belonging to the genus Typhlodromips have been recorded from Korea (Ryu, 2007, 2012). In the present paper, a new species, Typhlodromips geumgangensis is described from

*Comesponding author: moryu@sen.go.kr

Received June 7 2013; Revised August 122013

Accepted August 212013 this country, and a newly recorded Korean species, Typhlodromips paraki (Ehara, 1967) is redescribed, and key to the species of the genus Typhlodromips is provided. The setal nomenclature was based on that of Rowell et al. (1978). All measurements are given in micrometers. Length of dorsal shield is distance between bases of setae $\mathrm{j} 1$ and $\mathrm{J} 5$, width of that is distance between base of the seta $\mathrm{s} 4$.

Key to the specie of the genus Typhlodromips (adult female)

1. Macroseta on basitarsus IV shorter than or as long as that on genu IV

- Macroseta on basitarsus IV longer than that on genu IV *.

2. Macroseta on basitarsus IV shorter than that on genu IV T. mountus

- Macroseta on basitarsus IV as long as that on genu IV $\cdots$ 
T. arcus

3. Seta Z4 longer than distance between bases of Z4 and Z5 4

- Seta Z4 shorter than or as long as distance between bases of $\mathrm{Z} 4$ and $\mathrm{Z5}$

5

4. Preanal pores between and behind the posterior preanal setae (JV2) T. theae

- Preanal pores between the posterior preanal setae (JV2) *.

T. rademacheri

5. Seta Z4 much shorter than distance between bases of Z4 and $\mathrm{Z5}$

- Seta Z4 nearly as long as distance between bases of Z4 and $\mathrm{Z} 5$ 8

6. Dorsal shield reticulate only along margins

T. okinawanus

- Dorsal shield wholly reticulate ... 7

7. Spermatheca with disc-shaped cervix $\cdots \cdots \cdots \cdots . . .7$. quaesitus

- Spermatheca with V-shaped cervix ………..... T. paraki

8. Seta Z5 more than twice as long as Z4 ……................. 9

- Seta Z5 less than twice as long as Z4 ……………........ 11

9. Spermatheca with bell-shaped cervix ………... T. choii

- Spermatheca with distally widen, v-shaped cervix …… 10

10. Fixed digit with $12-14$ teeth

T. tsugawai

- Fixed digit with 6-7 teeth …….. T. geumganaensis n. sp.

11. Ventrianal pores just behind the posterior preanal setae (JV2)

T. volgini

- Ventrianal pores between the posterior preanal setae (JV2)

T. oguroi

\section{Typhlodromips geumgangensis n. sp. 금강이리응애 (신칭)}

(Figs. 1-7)

Female: Dorsal shield reticulate; 338 long, 165 wide; at least 9 pairs of small pores. Setae on dorsal shield: Z5 being longest, serrate; $\mathrm{Z} 4$ slightly longer than $\mathrm{s} 4 ; \mathrm{j} 1$ shorter than $\mathrm{j} 3$; remaining setae much shorter, smooth. Peritreme extending to $\mathrm{j} 1$; peritrematal shield fused anteriorly with dorsal shield. Sternal shield with posterior margin nearly straight, with 3 pairs of setae; 1 pair of metasternal platelets longer than wide. Ventrianal shield much longer than wide, wider than genital shield, with lateral margins slightly concave; 3 pairs of preanal satae; 1 pair of crescentric preanal pores between and behind 2 setae of JV2. 4 pairs of setae on integument surrounding ventrianal shield; seta JV5 smooth. 2 pairs of slender metapodal platelets, posterior pair much larger. Spermatheca as V-shaped. Fixed digit of chelicera 6-7 teeth, with pilus dentilis; movable digit with 3 teeth. Chaetotaxic formula; genu II, 2-2/0, 2/0-1; genu III, 1-2/1, 2/0-1. Leg IV with 3 macrosetae, genu, tibia, and basitarsus; macroseta on basitarsus longer than that on tibia and genu. Lengths of setae $(n=2$, mean $): \mathrm{j} 127.2, \mathrm{j} 340.0$, j4 8.0, j5 8.0, j6 8.8, J2 9.2, J5 9.2, z2 31.2, z4 14.4, z5 8.0, Z1 10.0, Z4 54.4, Z5 126.0, s4 49.2, S2 12.0, S4 9.2, S5 8.4, r3 20.8, R1 12.0, JV5 48.4, macrosetae on leg IV; genu 51.2, tibia 44.4, basitarsus 72.0 .

Male: Not Known.

Type series. Holotype: 웅, Geumgang Estuary-weir, Seongsanmyeon, Gunsan-si, Jeollabuk-do, 18. VIII. 1997, on Persicaria hydropiper (L.) Spach; Paratype: 우, Geumgang Estuary-weir, Seongsan-myeon, Gunsan-si, Jeollabuk-do, 11. XI. 1996, on Persicaria hydropiper (L.) Spach. Type specimens of this species are deposited in the National Institute of Biological Resources, Korea.

Etymology. The specific name is derived from the type locality, Geumgang Estuary-weir.

Remarks. The female of $T$. geumgangensis n. sp. resembles that of T. tsugawai (Ehara, 1959) from Japan in the setal lengths on the dorsal shield, but differs from the latter in having 6-7 teeth instead of 12-14 teeth on the cheliceral fixed digit and the cervix of the spermatheca much shorter and thicker.

2. Typhlodromips paraki (Ehara, 1967) 명아주이리응애 (신칭) (Figs. 8-15)

Amnlyseius (Amblyseius) paraki Ehara, 1967: p. 216, figs. 16-20; Ehara and Yokogawa 1977, p. 52, figs. 10-16.

Neoseiulus paraki: Chant and McMurtry 2007, p. 29.

Typhlodromips paraki: Ehara and Amano 2004, p. 9.

Female: Dorsal shield reticulate; 364 long, 166 wide; at least 13 pairs of small pores. Setae on dorsal shield: Z5 being longest, barbs; Z4 slightly longer than s4; S2 as long as S4; S5 longer than $\mathrm{z} 2$. $\mathrm{z} 4$ and $\mathrm{Z1}$; $\mathrm{j} 1$ shorter than $\mathrm{j} 3$; remaining setae much shorter, smooth. Peritreme extending to seta 1 1; peritrematal shield fused anteriorly with dorsal shield.. Sternal shield with posterior margin nearly straight, reticulate, with 3 pairs of 

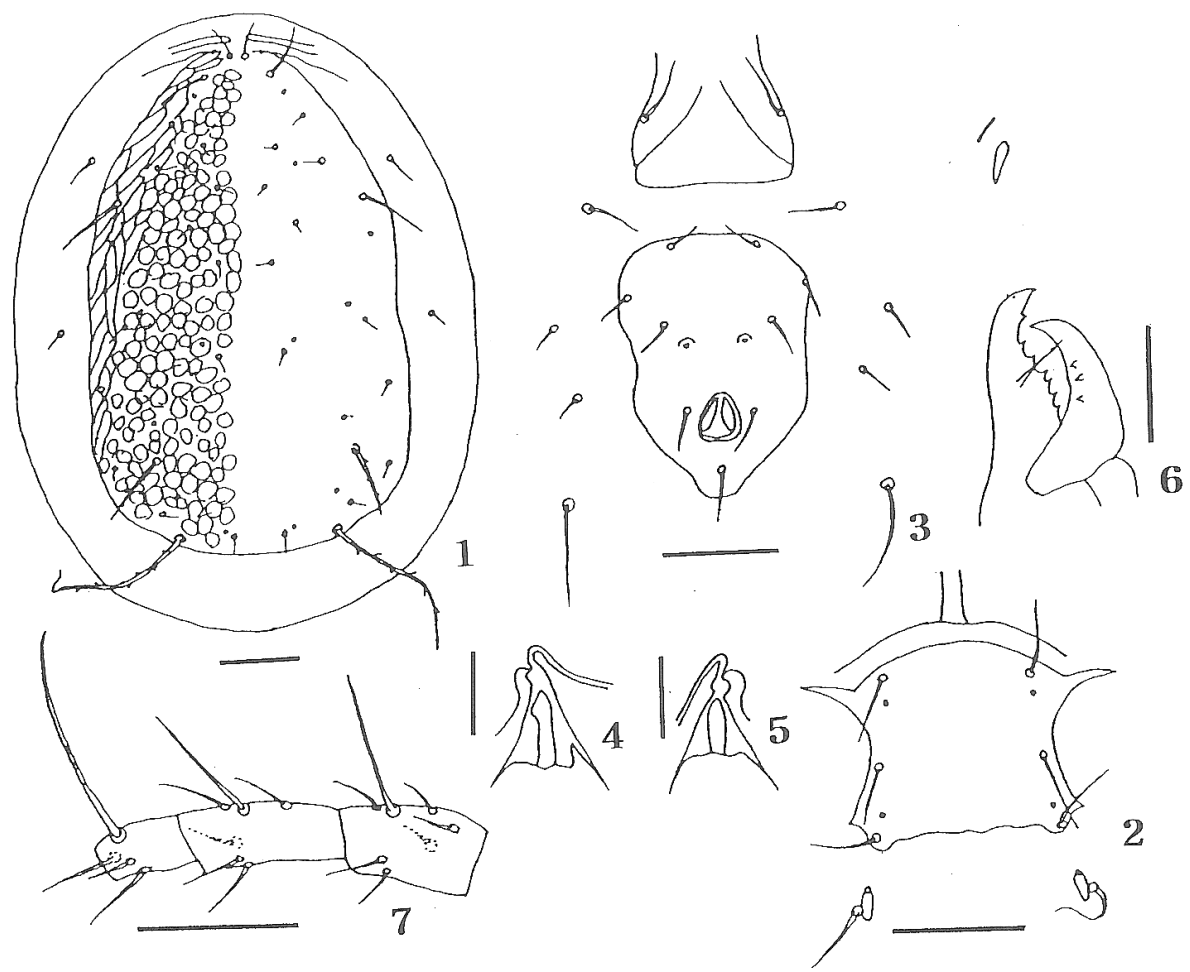

Figs. 1-7. Typhlodromips geumgangensisn. sp.( 6. Chelicera; 7. Basitarsus, tibia and genu of leg IV. (Scales: 1, 2, 3, 7 $=50 \mu \mathrm{m} ; 4,5=10 \mu \mathrm{m} ; 6=20 \mu \mathrm{m}$ ).

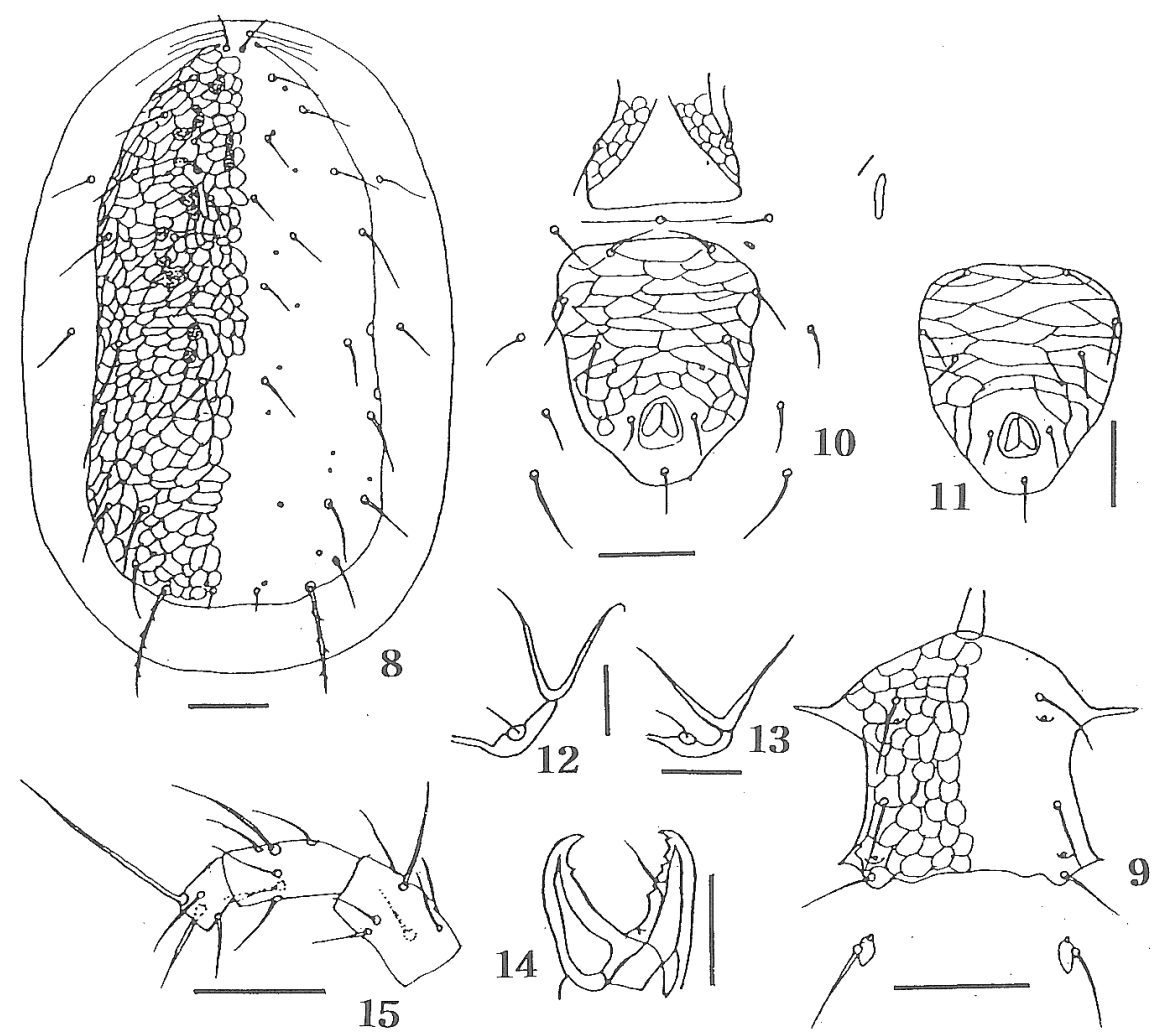

Figs. 8-15. Typhlodromips paraki( 9). 8. Dorsum of idiosoma; 9. Sternal shield; 10. Posterior ventral surface; 11. Ventrianal shield; $12-13$. Spermatheca; 14. Chelicera; 15. Basitarsus, tibia and genu of leg IV. (Scales: 8, 9, 10, 11, $15=50 \mu \mathrm{m} ; 12,13=10 \mu \mathrm{m} ; 14=20 \mu \mathrm{m}$ ). 
setae; metasternal platelets longer than wide. Ventrianal shield much longer than wide, wider than genital shield, with lateral margins slightly concave; 3 pairs of preanal satae; 1 pair of crescentric preanal pores between and behind 2 setae of JV2. Setae JV5 smooth. 2 pairs of slender metapodal platelets, posterior pair much larger. Spermatheca with V-shaped cervix; atrium well develeped. Fixed digit of chelicera 7 teeth, with pilus dentilis; movable digit with unidentate. Chaetotaxic formula; genu II, 2-2/1, 2/0-1; genu III, 1-2/1, 2/0-1. Leg IV with 3 macrosetae, genu, tibia, and basitarsus; macroseta on basitarsus much longer than that on tibia and genu. Lengths of setae ( $n=4$, mean): j1 25.4, j3 35.8, j4 19.8, j5 19.8, j6 24.8, J2 27.8, J5 12.4, z2 31.2, z4 33.4, z5 19.8, Z1 31.8, Z4 46.8, Z5 74.2, s4 42.8, S2 40.8, S4 39.8, S5 37.8, r3 33.4, R1 32.0, JV5 47.2, macrosetae on leg IV; genu 41.0, tibia 44.2, basitarsus 80.0.

Male: Not Known.

Distribution: Korea, Japan.

Material examined: 1 \& , 18. VIII. 1997, Chenopodium album var. centrorubrum Makino at Geumgang Estuary-weir, Ungpo-myeon, Gunsan-si, Jeollabuk-do; 2 우 우, 28. VIII. 1997, Chenopodium album var. centrorubrum Makino at Geumgang Estuary-weir, Napo-myeon, Gunsan-si, Jeollabuk-do; 1 ㅇ , 28. VIII. 1997, Lactuca indica var. laciniata (O. Kuntze) Hara at Geumgang Estuary-weir, Napo-myeon, Gunsan-si, Jeollabuk-do.

Remarks. The adult of this species is characterized by spermatheca with V-shaped cervix and atrium well developed.

\section{Acknowledgements}

This study was supported by the National Science Museum in Daejeon, Korea.

\section{Literature Cited}

Chant, D.A., McMurtry, J.A., 2007. Illustrated keys and diagnoses for the genera and subgenera of the Phytoseiidae of the world (Acari: Mesostigmata). Indira Publishing House, Publisher of books in Agricultural, Biological, Medical and veterinary Sciences, $220 \mathrm{pp}$.

Ehara, S., 1959. Some predatory mites of the genera Typhlodromus and Amblyseius from Japan (Phytoseiidae). Acarologia, 1: 285-295.

Ehara, S., 1967. Phytoseiid mites from Hokkaido (Acarina: Mesostigmata). J. Fac. Sci. Hokkaido Univ. Ser. 6 Zool., 16: 212-233.

Ehara, S. Yokogawa, M., 1977. Two new Amblyseius from Japan with notes on three other species (Acarina: Phytoseiidae). Proc. Jpn. Soc. Syst. Zool., 13: 50-58.

Ehara, S. Amano, H., 2004. Checklist and Keys to Japan Amblyseiinae (Acari: Gamasina: Phytoseiidae). J. Acarol. Soc. Jpn., 13: 1-30.

Rowell, H.J., Chant, D.A. Hansell. R.I.C., 1978. The determination of setal homologies and setal patterns on the dorsal shield in the family Phytoseiidae (Acarina: Mesostigmata). Can. Entomol., 110: 859-876.

Ryu, M.O., 2007. List of and key to the genera and species of the subfamily Amblyseiinae (Acari: Phytoseiidae) in Korea. Entomol. Res., 37: 251-260.

Ryu, M.O., 2012. Invertebrate Fauna of Korea. Phytoseiidae. NIBR, Ministry of Environment, Korea. Vol. 21, No. 18. 123 pp. 